\title{
CHALLENGES AND OPPORTUNITIES ASSOCIATED WITH DRYING ROUGH RICE IN FLUIDIZED BED DRYERS: A REVIEW
}

\author{
K. Luthra, S. S. Sadaka
}

\begin{abstract}
HighLIGHTS
- Fluidized bed drying of rice has several advantages that outweigh its disadvantages.

- Increasing the drying temperature above $60^{\circ} \mathrm{C}$ could reduce rice quality.

- Research related to energy and exergy efficiencies in fluidized bed dryers of rice is needed.
\end{abstract}

\begin{abstract}
Rice (Oryza sativa L.) is a staple food for more than half the world's population. World rice production reached approximately 740 million metric tons (MMT) in 2018 due to the ever-increasing demand driven by population and economic growth. Rice producers face challenges in meeting this demand, especially in developing countries where rice is prone to spoilage if the moisture content is not reduced to a safe level shortly after harvest. Rice producers, particularly in developing countries, typically use conventional drying methods, i.e., sun drying and natural air drying. These methods are time-consuming and environmentally dependent. On the other hand, fluidized bed drying, which is a well established technology, could provide rice producers with an effective drying technique that is quick, practical, affordable, and portable. Several innovative designs for fluidized bed dryers have been developed that could be installed on-farm or off-farm at a reasonable cost. Some studies have mentioned that the main advantage of fluidized bed drying is the increase in drying rate and the reduction of rice spoilage after harvest. Conversely, other studies have raised alarms regarding low rice quality, which is seen as a significant flaw of fluidized bed drying. Due to this lack of consensus, there is a great need to review this drying technology objectively. Therefore, this review article explores fluidized bed drying and details its advantages and disadvantages related to rice drying. It also sheds light on the effects of the operating parameters involved in fluidized bed drying, i.e., rice moisture content, drying temperature, airflow rate, air velocity, drying duration, and tempering duration, on dryer performance and rice quality. Several fluidized bed numerical models are also reviewed and evaluated. Additionally, this review explores the energy and exergy efficiencies of fluidized bed dryers and suggests opportunities for research associated with fluidized bed drying of rice.
\end{abstract}

Keywords. Energy, Exergy, Fluidized bed drying, Fluidized bed modeling, Moisture content, Rice quality, Rough rice, Tempering.

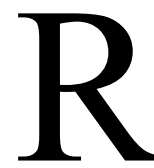
ice is the most common staple food in the world and is consumed by more than 3.5 billion people daily. The world's annual production of rice in 2018 reached approximately 732 MMT (USDAERS, 2018). About $90 \%$ of the world's rice production is harvested and used in Asia. Other areas of rice production include a few countries in South America, i.e., Brazil, Paraguay, and

\footnotetext{
cC)(-) $\Theta$ The authors have paid for open access for this article. This work is licensed under a Creative Commons AttributionNonCommercial-NoDerivatives 4.0 International License https://creative commons.org/licenses/by-nc-nd/4.0/

Submitted for review in October 2019 as manuscript number PRS 13760; approved for publication as a Review Article by the Processing Systems Community of ASABE in March 2020.

The authors are Kaushik Luthra, Graduate Student, Department of Biological and Agricultural Engineering, University of Arkansas, Fayetteville, Arkansas; Sammy S. Sadaka, Associate Professor, Department of Biological and Agricultural Engineering, University of Arkansas, Little Rock, Arkansas. Corresponding author: Sammy S. Sadaka, 2301 S. University Ave., Little Rock, AR 72204; phone: 501-6712298; e-mail:ssadaka@uaex.edu.
}

Uruguay, as well as the U.S. The U.S. was the fourth-largest exporter of rice in 2018, with an annual production of approximately 11.4 MMT. In the U.S., rice production occurs in the Central region (Arkansas, Mississippi, Missouri, Louisiana, and Texas) and the Sacramento Valley of California (Atwill, 2015). Arkansas has been the most crucial rice-producing state since 1973 , with about $47.9 \%$ of total U.S. rice production in 2018 (USDA-ERS, 2018). Rough rice is typically harvested at a moisture content above $20 \%$ wet basis (w.b.) The high moisture content of freshly harvested rice should be reduced quickly to a safe moisture content of $13 \%$ (w.b.) to avoid spoilage (Benado and Rizvi, 1985; Reddy et al., 2008).

\section{FLUIDIZED BED TECHNOLOGY}

Rough rice is dried on-farm by producers to preserve rice for personal use or for selling at higher prices in the off-season. Off-farm drying of rice is prevalent in the U.S., where most rice is dried after harvest at processing plants. Kunze and Calderwood (2004) reported that only about $20 \%$ of rice 
produced in the U.S. is dried on-farm using natural air or low-temperature air. Typically, with on-farm in-bin drying systems, in which the rice is dried slowly from the bottom to the top of the bin, prevailing weather conditions may not allow the drying front to move quickly enough through the grain mass. To overcome this slow drying rate, several promising drying technologies have been introduced, including cross-flow drying, layer drying, and fluidized bed drying. Fluidized bed (FB) drying is a well established technology that has been in use for almost three decades for drying rough rice (Tirawanichakul et al., 2004; Karbassi and Mehdizadeh, 2008; Tuyen et al., 2009).

FB dryers are the most commonly used type of dryers for chemicals, fertilizers, pharmaceuticals, and agricultural produce (Srinivasakannan et al., 2012). FB dryers show reasonable drying rates in particulate handling industries. The reasons for adopting FB dryers are good gas contact with the wet particles, high heat transfer between the gas and particles, reasonable circulation rates, and fast drying with excellent product quality compared to conventional dryers. To enhance the drying process with minimal energy usage, various researchers have reported modified designs for FB dryers (Tahmasebi et al., 2014; Jafari and Zare, 2017; Yahya et al., 2017) and have conducted experiments and developed theoretical models with different design modifications (e.g., microwave, ultrasonic, and solar).

Specific to rice drying in the U.S., there has been a debate on the use of FB drying. Numerous studies are in favor of commercializing this technology for drying rice due to the high drying rate, which can prevent spoilage and can dry large amounts of high-moisture rice. On the other hand, several studies are against the use of this technology and point to the lower head rice yields that result from FB drying.

No consensus is available on the use of FB drying for rice in the U.S. Thus, there is a need for a comprehensive review of the FB drying technology used for drying rice in the U.S. Accordingly, this review article explores FB drying technology and details its advantages and disadvantages related to rice drying. It also sheds light on the effects of the operating parameters involved in FB drying, i.e., rice moisture content, drying temperature, airflow rate, air velocity, drying duration, and tempering duration, on dryer performance and rice quality. Several FB numerical models are also reviewed and evaluated. Additionally, this review explores the energy and exergy efficiencies of FB dryers and suggests opportunities for research associated with FB drying of rice.

\section{The Debate about FB Drying of Rice}

As mentioned previously, FB drying is not new and is used commercially in Asia to dry rough rice (Sutherland and Ghaly, 1990). Research in Asia has recommended the use of FB drying of rice without compromising rice quality (Soponronnarit and Prachayawarakorn, 1994). However, due to the differences in climate, rice varieties, and the amount of throughput, FB drying of rice has not yet gained equivalent acceptance in the U.S. (Ondier et al., 2010). There are also differences in the results and recommendations of different researchers, as discussed in the following sections.

\section{FACtORS AfFecting Fluidized BED DRYING OF RICE}

For any perishable food product, drying for safe storage depends on several factors. Studies have short-listed a few factors that play a significant role in FB drying of rice. These factors include air temperature, air relative humidity, airflow rate, air velocity, initial moisture content of rice, drying and tempering duration, and the FB design (Banaszek and Siebenmorgen, 1990; Brook, 1992; Prakash and Pan, 2011; Sharada, 2013). Representative studies of FB drying of rice are summarized in table 1.

\section{Air Temperature}

The drying air temperature is the temperature at which the drying of rice occurs. The temperature of the rice bed equalizes with the heated air temperature in a short time. The inlet air temperature is inversely proportional to the drying time (Gazor and Mohsenimanesh, 2010). During the drying process, the air temperature affects the diffusion of moisture. At higher temperatures, the particles absorb more heat for water evaporation than at lower temperature, and hence the evaporation rate increases. The drying rate depends on the resident temperature of the solids in the bed (Da Silva et al., 2012). Reay and Baker (1985) reported that the bed temperature had a significant effect on the drying rate with both large and small particles. Giner and Calvelo (1987) performed FB drying of wheat and found that increasing the bed temperature from $40^{\circ} \mathrm{C}$ to $70^{\circ} \mathrm{C}$ decreased the drying duration by a factor of four. Sadaka et al. (2018) reported that the grain temperature increased, and the drying duration decreased, with an increase in air temperature.

For rice, several studies have used very high air temperatures (up to $150^{\circ} \mathrm{C}$ ) with $\mathrm{FB}$ drying and found that the drying rate increased with increasing air temperature (Soponronnarit, 1999; Taweerattanapanish et al., 1999; Karbassi and Mehdizadeh, 2008). Bonazzil et al. (1997) studied the effect of thermal shock on rice quality. They reported that no loss in rice quality occurred with temperatures ranging from $30^{\circ} \mathrm{C}$ to $90^{\circ} \mathrm{C}$. Similarly, Soponronnarit and Prachayavaracorn (1994) found that any air temperature less than $115^{\circ} \mathrm{C}$ was suitable for drying rice. However, some researchers have reported otherwise. Cnossen and Siebenmorgen (2000) mentioned that any temperature above $60^{\circ} \mathrm{C}$ reduced the head rice yield (HRY).

Thus, there is no explicit agreement on the optimum drying air temperature for rough rice. Previous studies have clearly shown that the highest acceptable drying temperature, that does not compromise rice quality, depends on the specific variety of rice.

\section{Air Relative Humidity}

The humidity of the inlet air has an inverse effect on the drying rate; it should be as low as possible for faster drying. Moisture in the air also has intense effects on the rate of evaporation and the temperature profile (Reyes et al., 2007). For drying to occur, the relative humidity of the drying air must be low enough so that the air can absorb moisture from the rice. Heating the air is the simplest way to lower its relative humidity. Brook (1992) reported that increasing the air 
Table 1. Studies of fluidized bed (FB) drying of rice along with their operating parameters and findings.

\begin{tabular}{|c|c|c|c|c|}
\hline Dryer Type & Study Objective & Operating Parameters & Findings & Reference \\
\hline FB & $\begin{array}{l}\text { To select the best model for drying } \\
\text { rough rice and determine the ef- } \\
\text { fects of operating variables on dry- } \\
\text { ing characteristics. }\end{array}$ & $\begin{array}{l}\text { Air temperature }\left(50^{\circ} \mathrm{C}, 60^{\circ} \mathrm{C} \text {, and }\right. \\
\left.70^{\circ} \mathrm{C}\right) \text {, air velocity }(2.3,2.5 \text {, and } \\
\left.2.8 \mathrm{~m} \mathrm{~s}^{-1}\right) \text {, and solids holdups of } \\
0.66 \text { and } 1.32 \mathrm{~kg} \text {. }\end{array}$ & $\begin{array}{l}\text { The Midilli et al. (2002) model was best } \\
\text { for describing the drying characteristics of } \\
\text { rice. Drying rate increased with increase in } \\
\text { air temperature and air velocity. }\end{array}$ & $\begin{array}{l}\text { Khanali et al. } \\
\text { (2012) }\end{array}$ \\
\hline FB & $\begin{array}{l}\text { To examine effects of high-temper- } \\
\text { ature FB drying and tempering on } \\
\text { pasting, gelatinization, crystalline, } \\
\text { and microstructural properties of } \\
\text { long-grain rice. }\end{array}$ & $\begin{array}{l}\text { Air temperature }\left(80^{\circ} \mathrm{C} \text { and } 90^{\circ} \mathrm{C}\right) \text {, } \\
\text { drying duration }(2.5 \text { and } 3 \mathrm{~min}) \text {, } \\
\text { tempering temperature }\left(75^{\circ} \mathrm{C} \text { and }\right. \\
\left.86^{\circ} \mathrm{C}\right) \text {, and tempering duration }(0 \text {, } \\
30,40 \text {, and } 60 \mathrm{~min}) .\end{array}$ & $\begin{array}{l}\text { Pasting properties and gelatinization en- } \\
\text { thalpy decreased with increasing tempera- } \\
\text { ture and tempering duration, while the } \\
\text { pasting and gelatinization temperature in- } \\
\text { creased. }\end{array}$ & $\begin{array}{l}\text { Truong et al. } \\
\qquad(2019)\end{array}$ \\
\hline $\begin{array}{l}\text { Solar-assisted } \\
\text { FB }\end{array}$ & $\begin{array}{l}\text { To introduce a less expensive dry- } \\
\text { ing option for drying rice. }\end{array}$ & $\begin{array}{l}\text { Air temperature }\left(100^{\circ} \mathrm{C} \text { to } 150^{\circ} \mathrm{C}\right) \text {, } \\
\text { bed depth }(10 \text { to } 11 \mathrm{~cm}) \text {, and air } \\
\text { velocity }\left(1.6 \text { to } 2.3 \mathrm{~m} \mathrm{~s}^{-1}\right) \text {. }\end{array}$ & $\begin{array}{l}\text { FB drying with ambient air ventilation } \\
\text { achieved dried rice quality similar to the } \\
\text { local practice. }\end{array}$ & $\begin{array}{l}\text { Jittanit et al. } \\
\qquad(2010)\end{array}$ \\
\hline $\begin{array}{l}\text { Cross-flow } \\
\text { FB }\end{array}$ & $\begin{array}{l}\text { To develop a mathematical model } \\
\text { and simulation of the rice drying } \\
\text { process. }\end{array}$ & $\begin{array}{l}\text { Air temperature }\left(50^{\circ} \mathrm{C} \text { to } 60^{\circ} \mathrm{C}\right) \\
\text { and feed rate } 1000 \mathrm{~kg} \mathrm{~h}^{-1} .\end{array}$ & $\begin{array}{l}\text { The experimental results fitted well with } \\
\text { the developed mathematical model. }\end{array}$ & $\begin{array}{l}\text { Izadifar and } \\
\text { Mowla (2003) }\end{array}$ \\
\hline $\begin{array}{l}\text { Vibrating } \\
\text { FB }\end{array}$ & $\begin{array}{l}\text { To examine the effect of FB drying } \\
\text { of rice and how the Page equation } \\
\text { fits the drying data. }\end{array}$ & $\left.240^{\circ} \mathrm{C}\right)$ & $\begin{array}{l}\text { Discoloration of rice was noted at about } \\
240^{\circ} \mathrm{C} \text { air temperature. The Page model fit } \\
\text { well with the experimental data. }\end{array}$ & $\begin{array}{l}\text { Ramesh and } \\
\text { Rao (1996) }\end{array}$ \\
\hline $\begin{array}{l}\text { Inclined bed } \\
\text { FB }\end{array}$ & $\begin{array}{l}\text { To determine the effect of inclined } \\
\text { bed drying after FB drying of rice. }\end{array}$ & $\begin{array}{l}\text { Dryer bed area, air temperature, air } \\
\text { relative humidity, and air velocity. }\end{array}$ & $\begin{array}{l}\text { Inclined bed drying with FB drying helped } \\
\text { to increase rice quality. }\end{array}$ & $\begin{array}{l}\text { Sarkar et al. } \\
(2014)\end{array}$ \\
\hline $\begin{array}{l}\text { Plug-flow } \\
\text { FB }\end{array}$ & $\begin{array}{l}\text { To develop a sequential method to } \\
\text { model continuous plug-flow FB } \\
\text { drying of rice. }\end{array}$ & $\begin{array}{l}\text { Initial moisture content of rice, air } \\
\text { temperature and velocity, and par- } \\
\text { ticle flow rate. }\end{array}$ & $\begin{array}{l}\text { The developed model was highly accurate } \\
\text { in predicting the final moisture content of } \\
\text { rice. }\end{array}$ & $\begin{array}{l}\text { Bizmark et al. } \\
\text { (2010) }\end{array}$ \\
\hline FB & $\begin{array}{l}\text { To investigate the cooking and } \\
\text { pasting properties of waxy rice af- } \\
\text { ter FB drying. }\end{array}$ & Air temperature $\left(90^{\circ} \mathrm{C}\right.$ to $\left.150^{\circ} \mathrm{C}\right)$. & $\begin{array}{l}\text { Thermal degradation of amylopectin gran- } \\
\text { ules at higher temperatures was noted and } \\
\text { led to easy digestion of the starch. }\end{array}$ & $\begin{array}{l}\text { Jaiboon et al. } \\
\qquad(2011)\end{array}$ \\
\hline FB & $\begin{array}{l}\text { To determine the effects of initial } \\
\text { rice moisture content, drying tem- } \\
\text { perature, and tempering on head } \\
\text { rice yield (HRY). }\end{array}$ & $\begin{array}{l}\text { Initial moisture content of rice } \\
(25 \%, 30 \% \text {, and } 35 \% \text { d.b. }) \text {, air } \\
\text { temperature }\left(110^{\circ} \mathrm{C}, 130^{\circ} \mathrm{C} \text {, }\right. \\
\left.150^{\circ} \mathrm{C} \text {, and } 170^{\circ} \mathrm{C}\right) \text {, and drying } \\
\text { time }(1,2,3 \text {, and } 4 \mathrm{~min}) \text {. }\end{array}$ & $\begin{array}{l}\text { Initial moisture content and tempering had } \\
\text { significant effects on HRY, and drying } \\
\text { temperature should not be greater than } \\
150^{\circ} \mathrm{C} \text { after the first stage of drying. }\end{array}$ & $\begin{array}{l}\text { Poomsa-ad } \\
\text { et al. (2005) }\end{array}$ \\
\hline FB & $\begin{array}{l}\text { To investigate the effects of FB } \\
\text { drying using superheated steam } \\
\text { and hot air on the physical proper- } \\
\text { ties of soaked rice. }\end{array}$ & $\begin{array}{l}\text { Fluidization velocity ( } 1.3 \text { to } 1.5 \\
\text { min) and soaking time in water ( } 3 \\
\text { to } 4 \mathrm{~h} \text { ). }\end{array}$ & $\begin{array}{l}\text { HRY and whiteness of rice were superior } \\
\text { with superheated steam compared to hot } \\
\text { air in FB drying. }\end{array}$ & $\begin{array}{l}\text { Rordprapat } \\
\text { et al. (2005) }\end{array}$ \\
\hline
\end{tabular}

temperature by $11^{\circ} \mathrm{C}$ reduced the relative humidity by about half. The heated air increases the temperature of wet rice, increasing the vapor pressure of the moisture within the rice, and thereby accelerating the evaporation of moisture to the heated air (Brook, 1992). When heating the air is not possible, the airflow can be increased to remove moisture at the required rate. Alternatively, the air relative humidity can be reduced by passing the humid air through a desiccant that absorbs moisture from the air; the desiccant can be regenerated thermally, as reported by Luthra and Sadaka (2019).

\section{Airflow Rate ANd Velocity}

The airflow rate, or the volume of air blown into the FB for drying, depends on the static pressure of the FB. The static pressure is estimated based on the rice depth and pressure losses, and thus the airflow rate can be determined (Brook, 1992; Sadaka, 2014). An increase in airflow rate in general increases the drying rate; as more air flows through the rice, more moisture is removed. Airflow is an essential factor in understanding FB behavior. The airflow should be determined carefully if the freeboard region has an open end. With a continuous FB drying system, an air collection system should be incorporated. Huynh et al. (1991) reported that a $0.3 \mathrm{~m}$ grain bed depth, which presented a static pressure of $1.3 \mathrm{~cm}$ of water, required an airflow rate of $6.5 \mathrm{~m}^{3}$ $\mathrm{min}^{-1} \mathrm{~m}^{-2}$. Reay and Baker (1985) reported that the drying rate for smaller particles was directly proportional to the airflow rate in FB drying. For solid by-products from an olive oil mill, Liebanes et al. (2006) suggested that increasing the airflow rate and air temperature increased the drying rate for FB drying. Topuz et al. (2004) found that the drying rate decreased with increasing airflow during FB drying of hazelnuts. Accordingly, the discharge of air through the blower should be optimum.

The minimum fluidization velocity is affected by the properties of the particles and of the air; thus, it is an essential factor for the design and operation of FB dryers. The moisture content of the particles decreased rapidly at higher air velocities (Djaeni et al., 2013). An increase in air velocity may also lead to an increase in bubble size in the FB. Particles are easily fluidized at high air velocities. As a result, mass transfer and heat transfer can easily occur in the bed. Unexpectedly, the air velocity, rather than the temperature, dominates the performance of FB dryers (Villegas et al., 2008).

\section{DRYING AND TEMPERING DURATIONS}

The drying duration is directly proportional to the moisture removed from the rice. Therefore, the drying duration depends on the initial moisture content and the targeted final moisture content of the rice. The drying duration also depends on the air temperature, relative humidity, and airflow rate.

Tempering reduces the moisture content gradient between the surface and center of the rice kernels that develops during drying. Many studies have reported a positive effect 
of tempering on HRY. Cnossen et al. (2003) tested three different drying conditions; for all conditions, the HRY increased with increasing tempering duration. Schluterman and Siebenmorgen (2007) tested tempering durations of 0 to $160 \mathrm{~min}$ for rough rice and found that the HRY increased with increased tempering duration. Poomsa-ad et al. (2001) and Soponronnarit (1999) showed the positive effect of tempering duration on rice quality using a fluidization technique.

\section{Initial Moisture Content}

The initial moisture content of rough rice also plays a significant role in determining the final moisture content and rice quality. Schluterman and Siebenmorgen (2007) showed that the final moisture content of dried rice is directly proportional to the initial moisture content of harvested rice. The drying rate of rice decreased with a decrease in moisture content. The drying rate also decreased with FB drying, as mentioned by Luthra et al. (2018) and Sadaka et al. (2018). The decrease in drying rate occurs because of the lack of surface water or free water during the later phase of drying. The bound water present in the later phase of drying requires more time to evaporate, and thus the drying rate decreases with a decrease in the initial moisture content of rice.

\section{Particle Size AND Density}

Fluidization depends on the properties of the particles, i.e., particle size and bulk density (Gong et al., 1997). Fluidization is smooth and homogenous for small and low-density particles. It can occur with a low airflow rate, and the growth and speed of the bubbles can be controlled. Different varieties of rough rice have significant variation in their dimensions, as reported by Bagheri et al. (2013). Short grain rice, medium grain rice, long grain rice, and extra-long grain rice have kernel lengths of $L<5.5 \mathrm{~mm}, 5.5 \mathrm{~mm} \leq L<6.5 \mathrm{~mm}$, $6.5 \mathrm{~mm} \leq L<7.5 \mathrm{~mm}$, and $L \geq 7.5 \mathrm{~mm}$, respectively. The bulk density of rough rice generally varies between 300 and $600 \mathrm{~kg} \mathrm{~m}^{-3}$, depending on the cultivar (Bagheri et al., 2013; Patel et al., 2013). The particle size and density change with different rice varieties (short, medium, long-grain, and extralong), which in turn changes the drying rate in FB dryers because the contact surface area changes. Ulku and Uckan (1986) reported that the drying rate increased in FB drying with an increase in the contact area or size of the particles.

\section{SOLIDS HoLduP}

Solids holdup is the amount of drying material in the FB. In a study on granular materials modeling, the drying rate decreased with an increase in solids holdup (Proctor, 1994). An increase in solids holdup decreases the bed temperature because there is more material to be dried, and therefore the drying rate decreases. Srinivasakannan and Balasubramanian (2006) studied FB drying of ragi, a cereal crop grown in Asia and East Africa, and concluded that the drying rate increased significantly with a decrease in solids holdup and an increase in air temperature.

\section{INTERDEPENDENT FACTORS}

Several of the previously mentioned factors, i.e., air temperature, relative humidity, airflow rate, air velocity, drying duration, tempering duration, and initial moisture content of rice, are dependent on each other. Many studies have reported the interdependency and correlation of these factors with each other. Brook and Foster (1982) reported that the drying duration increased with an increase in grain depth and a decrease in initial moisture content. Drying from $15 \%$ to $12.5 \%$ (w.b.) moisture content can be done for any desired period (Mrema et al., 2012). Mrema et al. (2012) reported that rice below $15 \%$ (w.b.) moisture content can be safely stored for an extended period, as long as an airflow of at least $2.7 \mathrm{~m}^{3} \mathrm{~min}^{-1} \mathrm{t}^{-1}$ is applied, which is satisfactory for maintaining rice quality. For wetter rice and unfavorable conditions, an airflow of $3.5 \mathrm{~m}^{3} \mathrm{~min}^{-1} \mathrm{t}^{-1}$ is required.

Supplemental heat has been used to increase the air temperature during cold weather or at night to keep the relative humidity low. Supplemental heat also reduced the drying time by $25 \%$ to $65 \%$ compared with using airflow without supplemental heat (Mrema et al., 2012). Misra and Brooker (1980) suggested that the air temperature had the most significant effect on the drying rate, whereas airflow and air relative humidity had minor effects. They even suggested that air relative humidity can be ignored as a factor in determining the drying rate for thin-layer modeling. Bonazzil et al. (1997) found similar results, i.e., the drying time for rice was 20 times faster at $80^{\circ} \mathrm{C}$ than at $30^{\circ} \mathrm{C}$ and seven times faster than at $45^{\circ} \mathrm{C}$. They also reported that drying increased with lower relative humidity of the air; however, similar to Misra and Brooker (1980), they considered relative humidity to be much less important than air temperature.

\section{Advantages And Disadvantages OF FLUIDIZED BED DRYING}

FB drying has many advantages, including: (1) The rice is thoroughly mixed, which leads to homogeneity of the thermal treatment and ensures uniform drying with a high drying rate (Wimberly, 1983; Avidan and Yerushalmi, 1985; Kassem et al., 2011). (2) The turbulence in the bed creates high heat and mass transfer rates, which allow a shorter drying duration (Richardson, 1971; Avidan and Yerushalmi, 1985). (3) Large amounts of rice can be moved quickly in the fluidized state, which improves product handling (Avidan and Yerushalmi, 1985). (4) FB drying can accommodate varying particle sizes (Avidan and Yerushalmi, 1985). (5) FB drying can significantly reduce the drying duration compared to conventional drying methods (Sutherland and Ghaly, 1990; Srinivasakannan and Balasubramaniam, 2006). (6) FB drying requires a reasonable initial investment compared to some conventional methods (Wimberly, 1983; Sopanronnarit et al., 1998; Gazor and Mohsenimanesh, 2010).

Notwithstanding the above advantages, there are also a few disadvantages of FB drying, which include: (1) The design and structure of FB dryers are more complicated compared to conventional dryers (Avidan and Yerushalmi, 1985). (2) Scale-up of FB drying can be challenging (Avidan and Yerushalmi, 1985). (3) Erosion of the FB dryer walls can be an issue and can require maintenance (Avidan and Yerushalmi, 1985). (4) FB drying produces an increased 
amount of particle breakage (Kunze, 1983). (5) High energy costs are associated with FB dryers. (6) The dried rice requires tempering before further processing, i.e., milling (Villegas et al., 2010).

\section{Challenges With FB DRYing OF Rice}

Apart from the abovementioned advantages and disadvantages, there are some challenges associated with the application of FB drying technology for rice. Feeding of rice into the FB drying column can be challenging because the entire column cannot be filled at once. Separation of the dried rice from the incoming wet rice is another challenge, especially when the FB dryer is operating with high airflow. At high airflow, the moving grain creates more wear on the dryer walls; thus, dryer maintenance can be a challenge. An additional challenge is dust blown upward due to the higher airflow. Dust production increases due to kernel-to-kernel and kernel-to-wall friction. Consequently, managing the dust can be a challenge, and there is a risk of dust combustion. Kauffman (1987) reported that dust explosions can cause injuries, disrupt the drying and milling process by affecting the equipment, and cause financial loss.

Another challenge is the scaling-up of laboratory FB dryers for commercial use (Matsen, 1996; Daud, 2008). A limited number of theoretical models exist for FB drying that can replace the expense of numerous pilot-plant trials. Theoretical modeling of a scaled-up FB dryer is difficult because the bubbling characteristics and mixing behavior differ greatly with the variation in size from laboratory scale to industrial scale. This limitation requires testing at both laboratory scale and pilot-plant scale to formulate a scaling-up plan for the dryer. Thus, it is essential to determine a method for reducing the costs of pilot-plant experiments (Knowlton et al., 2005).

\section{Heat TRANSFer in FB DRYers}

Heat transfer in FB dryers can occur in two ways. The first form of heat transfer occurs between the air and the solid particles, as in many other processes. The second form of heat transfer occurs between the bed phases, i.e., bubbles, clouds, and emulsion, which exist only in FB systems. The bubbles in FB systems act like liquid bubbles with low viscosity. FB systems are characterized by excellent heat transfer between the fluidized layer and the heating surfaces (Roy and Sarma, 1970).

\section{DRYING RICE IN FB DRYERS}

Various designs of FB dryers have been developed. Based on their structural design, there are four FB categories: static, vibrating, circulating, and annular (Hemis et al., 2019). Novel techniques are also used in combination with FB drying, such as microwave-assisted or infrared-assisted FB drying, solar-assisted FB drying, inclined bed drying combined with FB drying, impinging steam combined with FB drying, and continuous plug-flow FB drying (Wimberly et al., 1983).

Solar FB dryers can work on-farm, with their energy requirements met by solar energy, providing a solution for offgrid farmers in developing countries (Sopanronnarit et al., 1998; Yahya, 2016). Jafari and Zare (2017) used ultrasound with FB drying to investigate the drying effects on rice quality. Meeso et al. (2004) used far-infrared irradiation to dry rough rice with $\mathrm{FB}$ drying. The irradiation time was 0.5 to 1.0 min with a radiative intensity of 0.310 to $0.707 \mathrm{~W} \mathrm{~cm}^{-2}$ and 1 to 2 min of tempering. Temple et al. (2000) used multistage FB drying with air recirculation. Kozanoglu et al. (2013) studied the drying kinetics of rough rice in a reduced superheated steam FB system and found that the drying rate increased with an increase in drying air temperature. Sarker et al. (2017) studied rice quality during the drying process using an inclined FB. Ramesh and Rao (1996) used a vibrating FB dryer to dry rice at temperatures ranging from $160^{\circ} \mathrm{C}$ to $240^{\circ} \mathrm{C}$. Rordprapat et al. (2005) used superheated steam in FB dryers to investigate the physical properties of rough rice during drying. An airflow rate of 1.3 to 1.5 times the minimum fluidization velocity was used with 3 to $4 \mathrm{~h}$ of soaking time in water. The results showed that HRY and whiteness improved with the use of superheated steam as compared to hot air.

Stakic and Urosevic (2011) studied a vibrating FB dryer experimentally and with simulations using fine-grained materials. They reported that the temperature differences in the bed were almost negligible $\left( \pm 1.0^{\circ} \mathrm{C}\right)$ due to the mixing of particles. Comparison of the drying kinetics, experimentally and numerically, showed that a higher airflow rate and temperature increased the drying rate. This effect was pronounced for deeper beds because of the greater amount of grain to be dried using the equivalent drying capacity. In a study on jasmine rice, Atthajariyakul and Leephakpreeda (2006) adapted a fuzzy logic technique optimized for quality control with FB drying. They concluded that a drying temperature of $150^{\circ} \mathrm{C}$ with $33 \%$ initial moisture content and 90 min of tempering were the best conditions for drying.

\section{RESEARCH SUPPORTING FB DRYING OF RICE}

Wiset et al. (2001) dried rough rice with two different FB drying treatments. The first treatment involved drying at $90^{\circ} \mathrm{C}$ for $11 \mathrm{~min}$, and the second treatment was two-stage drying: fluidization until $18 \%$ (w.b.) moisture content, followed by drying in storage using ambient air. For the second treatment, the HRY did not decrease, as in the first treatment. Poomsa-ad et al. (2001) included tempering in their experimental design and showed that tempering helped in achieving an acceptable HRY with FB drying. Thakur and Gupta (2006) compared FB and fixed bed drying of rough rice and concluded that the energy use could be reduced by half and the drying rate enhanced with FB drying, without compromising rice quality. Sarker et al. (2017) reported acceptable HRY and whiteness for rice dried in an inclined bed FB dryer. Wetchacama et al. (2000) reported a 5\% greater HRY in a commercial-scale FB dryer as compared to fixed bed ambient air drying. Using Vietnamese rice varieties, Tuyen et al. (2009) tested the effects of high-temperature FB drying along with tempering. They found that the HRY increased tremendously with tempering for $40 \mathrm{~min}$, and the hardness of the rice kernels was greater with FB drying as compared to thin-layer drying. Improved HRY was also reported by Meeso et al. (2004). They used far-infrared irradiation and tempering with FB drying and achieved a 58\% maximum 
HRY, which was higher than the control samples. Rattanamechaiskul et al. (2016) reported an increase in HRY for purple rice using hot-air FB drying; the maximum HRY reported was $46 \%$. Sarker et al. (2013) reported no difference in the HRY using ambient air drying and FB drying. Jafari and Zare (2017) studied the drying behavior and energy consumption for rough rice using an ultrasonic FB dryer. Their objective was to study the influence of high-power ultrasound on FB drying of rice based on the relationships of drying kinetics, grain quality (kernel bending strength and percentage of cracked kernels), and specific energy consumption. Application of high-power ultrasound in conjunction with traditional FB drying resulted in a $23 \%$ decrease in drying time as well as enhanced grain quality, as measured by percentage of cracked kernels and kernel bending strength.

Parboiling of rough rice is a process that requires drying. Parboiling increases the nutritional value, improves the quality of cooked rice, and decrease the breakage of milled rice. Parboiling is conducted in three stages: soaking, steaming, and drying. Prachayawarakorn et al. (2018) combined microwave and hot-air FB (MWFB) to produce parboiled rice. They tested the effects of bed depth, drying temperature, and microwave power on drying time. Their results showed that the drying time was shorter with a shallower bed, higher drying temperature, and higher microwave power. The drying temperature, bed depth, and microwave power strongly affected the gelatinization of rice starch. The parboiled rice produced by MWFB resulted in insignificant broken kernels ( $1 \%$ to $2 \%$ ). Increasing the drying time, initial grain temperature, drying temperature, and microwave power decreased the whiteness and increased the specific energy consumption. The researchers recommended MWFB for producing parboiled rice with a complete degree of starch gelatinization without the need for steaming. Production of parboiled rice with the $\mathrm{FB}$ at $170^{\circ} \mathrm{C}$, initial grain temperature of $32^{\circ} \mathrm{C}$, and bed depth of $5 \mathrm{~cm}$ had a $32 \%$ lower specific energy consumption than the conventional parboiling process.

Soponronnarit et al. (2006b) tested a pilot-scale superheated-steam FB dryer for parboiled rice. They found that a fluidization velocity of 1.3 to 1.5 times the minimum fluidization velocity had no significant effect on the drying rate. The drying temperature had a significant effect on the parboiled rice quality, as measured by whiteness, water adsorption, and pasting viscosity. The starch gelatinization during drying resulted in higher HRY for the parboiled rice as compared with raw rice. The energy consumption for reducing the moisture content of rough rice from $43 \%$ to $22 \%$ (d.b.) reached 7.2 MJ kg-1 water evaporated. Similarly, Taechapairoj et al. (2003) recommended FB drying of rice using superheated steam as an alternative to hot air. The mass transfer mechanism for drying rough rice with an initial moisture content of $25 \%$ to $44.5 \%$ (d.b.) was significantly affected by the movement of moisture inside the kernels. The researchers reported that the drying rate and drying time were functions of the drying temperature and bed depth. They stated that the HRY with superheated steam drying was superior to the HRY obtained with hot-air drying. On the other hand, the color of the rice was darker with superheated steam drying, which is an inferior quality attribute.
Srimitrungroj et al. (2019) investigated the drying characteristics and quality of rough rice dried with hot air and with humidified hot-air fluidization. They soaked rough rice with an initial moisture content of $14 \%$ (d.b.) in hot water at a temperature of $70^{\circ} \mathrm{C}$ for $5 \mathrm{~h}$. They then dried the rice with air temperatures of $130^{\circ} \mathrm{C}, 150^{\circ} \mathrm{C}$, and $170^{\circ} \mathrm{C}$, relative humidity in the range of $0.3 \%$ to $12 \%$, air velocity of $3.9 \mathrm{~m} \mathrm{~s}^{-1}$, and bed height of $10 \mathrm{~cm}$. The rice quality was determined based on the HRY, degree of gelatinization, and color of the dried rice. The results showed that humid hot-air drying required more time than hot-air drying. The degree of starch gelatinization was significantly higher with humid hot-air drying as compared with hot-air drying because the former method provided a higher grain temperature and slower drying rate. The HRY was also higher with humid hot-air drying than with hot-air drying. However, the color of the dried rice obtained with humid hot-air drying was browner for the drying temperature range used. The researchers recommended that humid hot-air drying could be performed at temperatures of up to $170^{\circ} \mathrm{C}$, relative humidity of $6 \%$, and a degree of milling of $10 \%$ to produce parboiled rice.

\section{RESEARCH AGAINST FB DRYING OF RICE}

The concept of glass transition, introduced by Cnossen and Siebenmorgen (2000), suggests that fissuring of rice kernels occurs if the kernels are heated above $60^{\circ} \mathrm{C}$. This finding questions the use of FB drying with air temperatures above $60^{\circ} \mathrm{C}$, which is common. Soponronnarit (1999) used an air temperature of $115^{\circ} \mathrm{C}$ for $\mathrm{FB}$ drying of rough rice and reported a reduction in rice quality. Karbassi and Mehdizadeh (2008) performed FB drying of rough rice at $140^{\circ} \mathrm{C}$ for 2 min and found that the HRY decreased, along with cooking properties and nutritional quality. Jaiboon et al. (2009) found that the HRY of waxy rice was less with FB drying than with shade drying, and tempering did not improve the HRY. Ramesh and Rao (1996) used a vibrating FB dryer at temperatures between $160^{\circ} \mathrm{C}$ and $240^{\circ} \mathrm{C}$ to dry rice and reported that a substantial color change occurred in the rice.

Prasad et al. (1994) conducted drying experiments on parboiled rough rice in stationary, semi-fluidized, and fluidized drying conditions. They tested bed thicknesses of 10,15 , and $20 \mathrm{~cm}$ at drying air temperatures of $40^{\circ} \mathrm{C}$ to $80^{\circ} \mathrm{C}$ for the three drying conditions. They reported that the stationary bed with $20 \mathrm{~cm}$ depth achieved a maximum overall thermal efficiency of $47.4 \%$ at a drying air temperature of $80^{\circ} \mathrm{C}$. The parboiled rough rice could be dried in semi-fluidized conditions without any significant milling loss, and the drying time was reduced as compared to stationary bed conditions. A high drying rate was obtained at lower bed thicknesses with semi-fluidized conditions. An extensive loss in HRY in milling and higher energy consumption were found with fluidized conditions. The researchers recommended that parboiled rough rice should not be dried in FB dryers due to extensive loss in HRY and higher energy consumption.

Soponronnarit et al. (2006a) used a superheated steam fluidization method for parboiling of brown rice. The influence on product quality of soaking temperature, time, steaming temperature, and bed depth was evaluated based on HRY, whiteness, and viscosity of the rice flour. The initial 
moisture content of the rice was $12.8 \%$ (d.b.). The researchers tested soaking temperatures of $70^{\circ} \mathrm{C}$ to $90^{\circ} \mathrm{C}$, soaking times of 0.5 to $2.0 \mathrm{~h}$, steam temperatures of $120^{\circ} \mathrm{C}$ to $160^{\circ} \mathrm{C}$, steam velocity of $3.9 \mathrm{~m} \mathrm{~s}^{-1}$, and bed depths of 8 to $12 \mathrm{~cm}$. They reported that lower HRY was observed when the final moisture content was reduced below $28 \%$.

\section{FLUIDIZED BED MODELING}

For rice drying in FB dryers, environmental factors, such as air temperature and humidity, are essential, and the FB dryer parameters (i.e., aspect ratio, bed temperature, airflow rate, and minimum fluidization velocity) and grain parameters (i.e., initial moisture content, size, and density) must also be considered. Drying models, also referred to as mathematical models, are essential for understanding the impacts of the factors that affect the drying process. Drying models are used as tools to explain the drying phenomena using mathematical equations (Gunhan et al., 2005).

Generally, there are two broad classifications of models in any area of research: empirical models and theoretical models. Empirical models are developed by fitting experimental data to a mathematical equation (Chen and $\mathrm{Wu}$, 2000). Empirical models for rice drying are mostly based on exponential equations. Empirical models can be easy to implement; however, they are restricted to the range of operating conditions for which they were developed. On the other hand, theoretical models are developed using heat and mass transfer equations ( $\mathrm{Wu}$ et al., 2004). These models can be applied to a wide range of operating conditions; however, they are complex to implement.

Empirical models, i.e., kinetic models, describe the drying kinetics of rice, which generally occurs in two phases: a falling rate period and a constant rate period. The constant rate drying period is modeled using correlation models between the drying rate and the influencing parameters or by using coefficients for heat and mass transfer between solids and fluids (Srinivasakannan and Balasubramanian, 2008). Tahmasebia et al. (2014) performed a kinetic study on microwave and FB drying. The drying kinetics with nitrogen FB, superheated steam FB, and microwave drying were investigated. The microwave drying data were best described by the Page model, indicating a difference in kinetics between the two drying methods. This difference was attributed to different heat transfer mechanisms between conventional and microwave drying.

Zare et al. (2012) established a comprehensive dimensionless model of rough rice drying from a validated partial differential equation (PDE), applying the dimensional analysis of the Buckingham theorem. This comprehensive dimensionless model used all the drying parameters in one equation to predict grain moisture content during the drying process. Statistical measures, including the coefficient of determination $\left(\mathrm{R}^{2}\right)$, chi-square $\left(\chi^{2}\right)$, mean relative deviation (MRD), and root mean square error (RMSE), were used to compare the validated PDE model with the dimensionless model. The researchers reported that the data from the PDE model fitted well with the generalized dimensionless model.
They also found good agreement between the generalized dimensionless model and experimental drying data. The results indicated that the generalized dimensionless model could predict the rough rice moisture content with reasonable accuracy. Because the generalized dimensionless model was simple and considered all the drying parameters in one equation, it was easy to use for the prediction of grain moisture content.

Numerical models have also been widely used by researchers because of their accuracy. The two most common types of numerical FB models are single-phase models and multi-phase models. In a single-phase model, the FB is considered as a single mass. Heat and mass balances are used for the FB, and the particles are assumed to be perfectly mixed (Martinez-Vera et al., 1995). On the other hand, multi-phase FB models comprise a bubble phase (dilute phase) and a suspension phase (dense phase). Some researches have assumed that the suspension phase is composed of the particles and the intermediate gas phase (Zahed et al., 1995; Burgschweiger et al., 1999). Fick's equation has been used in FB drying studies, and it assumes that all the rice kernels are exposed to standard conditions (Srinivasakannan and Balasubramanian, 2008). However, this assumption has been questioned by researchers due to the reported dependence of the shape of the drying column and the amount of drying mass on the effective diffusivity. In recent years, Fick's laws of diffusion have been used to model the moisture gradient within a single rice kernel. These models describe the average moisture content of a single kernel as well as the moisture gradient between the surface and center of the kernel. These single-kernel models are useful for understanding the problem of rice fissuring. A few studies have used heat transport phenomena in their models (Yang et al., 2002; Meeso et al., 2007). These models differ based on the varieties of grain used due to differences in thermal, physical, and quality-related properties (Basunia and Abe, 1998).

Researchers have discussed numerical models for FB drying. Gong et al. (1997) proposed a two-dimensional finite element model using one-dimensional cylindrical geometry to model wheat particles. They accurately described the heat and mass transfer of wheat in a rotating jet spouted bed. Villegas et al. (2008) used a lumped mechanistic model to estimate the temperature and moisture content of particles in a batch FB dryer. Inaba et al. (2007) developed an energy and exergy FB model to investigate the effects of heat and mass transfer on the drying efficiency of wheat and corn. They found that the energy and exergy efficiency decreased with a decrease in moisture content. Nejadi and Nikbakht (2017) developed a single-phase numerical model to predict the moisture content of corn and to describe the heat and mass transfer in an infrared-assisted FB dryer, assuming the bed to be continuous. Izadifar and Mowla (2003) used a crossflow continuous FB dryer to develop a numerical model for simulating the drying process in which relative humidity, air temperature $\left(50^{\circ} \mathrm{C}\right.$ to $\left.60^{\circ} \mathrm{C}\right)$, initial moisture content, and feed rate $\left(1000 \mathrm{~kg} \mathrm{~h}^{-1}\right)$ were the variables. Good agreement was obtained between the model output and experimental results. Bizmark et al. (2010) developed a sequential model for a continuous plug-flow FB dryer using initial moisture content, airflow, and particle flow rate as variables. Their model 
estimated the final moisture content of rough rice with less than $4.5 \%$ inaccuracy.

Khanali et al. (2014) conducted simulations and experiments on a plug-flow FB dryer using inert dry solids to determine the outlet gas humidity and temperature. Their model was extended to determine the mass and energy transfers between solid and gas phases in dynamic conditions. Drying of rough rice in a laboratory-scale plug-flow FB dryer was investigated in dynamic conditions to validate the model. A very acceptable agreement between the simulated and measured results was achieved. Additionally, Xiao et al. (2012) performed CFD modeling, simulation, and experiments on the drying characteristics of rapeseed using a superheated steam FB dryer. The simulated drying curve obtained from the drying model was in good agreement with the experimental results. A negative drying rate occurred in the first period, caused by initial steam condensation, that lasted for about $6 \mathrm{~s}$, and the moisture content of the material increased to a maximum.

\section{ENERGY AND EXERGY EFFICIENCIES OF FB DRYERS}

Several studies have reported the energy and exergy efficiencies of FB dryers of various designs and with various bed materials. However, there is a lack of studies on the energy and exergy analysis of rice drying in FB dryers, so this section presents a general discussion of the energy and exergy efficiencies of FB dryers. Energy efficiency is defined as the energy used for moisture evaporation divided by the energy consumed in the drying air for the extent of the drying duration. This definition emphasizes moisture removal, and it excludes the temperature of the material. Exergy efficiency is used to assess the drying parameters throughout the duration of drying. The exergy efficiency is usually less than the energy efficiency because of entropy. However, it follows the same trend.

Nazghelichi et al. (2011) analyzed the energy and exergy performance of FB drying. Their drying experiments used carrot cubes with dimensions of 4,7 , and $10 \mathrm{~mm}^{3}$, inlet air temperatures of $50^{\circ} \mathrm{C}, 60^{\circ} \mathrm{C}$, and $70^{\circ} \mathrm{C}$, and bed depths of 30 , 60 , and $90 \mathrm{~mm}$. The effects of the drying variables on energy utilization, exergy utilization ratio, exergy loss, and exergy efficiency were studied. The exergy efficiency was found to be in the range of $10.3 \%$ to $70.7 \%$. The results showed that the exergy efficiency had its maximum value with higher drying air temperature, small cube size, and shallower bed depth. Karagüzel et al. (2012) recommended FB drying based on exergy and energy analyses of chickpea and bean drying. The drying process was evaluated at different temperatures and air velocities for both products. Exergy analysis was used to determine the exergy efficiency during drying based on the second law of thermodynamics. The parameters that influenced the exergy efficiency were determined, and the exergy efficiency was shown to be proportional to the drying air temperature and velocity. The exergy efficiency for the same drying air temperature $\left(47.1^{\circ} \mathrm{C}\right)$ was $56 \%$ to $65 \%$ for bean and $45 \%$ to $62 \%$ for chickpea. Yogendrasasidhar and Setty (2018) performed energy and exergy analyses with a wall-heated batch FB dryer using kodo millet grain and fenugreek seed. The energy and exergy analyses were performed by changing the wall temperature, air velocity, bed height, and initial moisture content of the bed material in the wall-heated FB dryer. The energy utilization ratio, exergy loss, and exergy efficiency of kodo millet and fenugreek seed were reported. The exergy efficiencies for kodo millet and fenugreek seed ranged from $40 \%$ to $72 \%$ and from $40 \%$ to $75 \%$, respectively. The exergy efficiencies increased for both kodo millet and fenugreek seed with increasing wall temperature, air velocity, and drying time and decreased with increasing bed height and initial moisture content.

Ozahi and Demir (2013) developed a model to analyze the exergy of a batch FB dryer. An innovative model for thermodynamic analysis of a batch FB dryer was proposed by considering two distinct systems, i.e., the drying air medium and the particles to be dried. The energy and exergy efficiencies evaluated using the proposed model were compared with those in previous studies. The researchers found good conformity with an acceptable error margin of $9 \%$. A relationship was developed with a mean deviation of $10 \%$ to evaluate the energy efficiency of corn drying as well as the drying processes for other particles at an air temperature of $50^{\circ} \mathrm{C}$. The researchers concluded that exergy analysis, along with energy analysis, is necessary to estimate optimum FB conditions.

Correspondingly, Assari et al. (2013) used a two-fluid simulation model for a batch FB dryer to analyze the energy and exergy of the dryer. The two-fluid model was used to optimize the input and output and maintain the product quality. The two-fluid model was based on a continuum postulation of the two phases. Two sets of conservation equations were applied for the solid and gas phases and were considered as an interpenetrating range. This study also considered two-dimensional, axisymmetric cylindrical energy and exergy equations for both phases, and numerical simulation was performed. The effects of the inlet gas velocity, inlet gas temperature, and particle size diameter on the energy and exergy efficiencies were studied. The two-fluid model prediction indicated good agreement between the reported non-dimensional correlations and experimental results. At the beginning of the drying process, the energy efficiency was higher than the exergy efficiency for a short duration. However, these efficiencies became close to each other in the final stage of the drying.

Azadbakht et al. (2017) performed energy and exergy analyses using artificial neural network (ANN) modeling for FB drying of potato cubes. Drying was modeled with inlet air temperatures of $45^{\circ} \mathrm{C}, 50^{\circ} \mathrm{C}$, and $55^{\circ} \mathrm{C}$, air velocities of $0.05,0.11$, and $0.15 \mathrm{~m} \mathrm{~min}^{-1}$, and bed depths of $1.5,2.2$, and $3.0 \mathrm{~cm}$. The effects of these factors on energy utilization, energy efficiency, utilization ratio, and exergy loss and efficiency were evaluated. Furthermore, the ANN was used to predict the energy and exergy parameters. The thermodynamic drying process was also simulated using the model. The results showed that the energy utilization, efficiency, and utilization ratio increased with increasing bed depth and air velocity. The energy utilization and efficiency also increased with increasing temperature. The exergy loss and efficiency increased with increasing bed depth, air velocity, and temperature. 
Various researchers (e.g., Srinivasakannan et al., 1994; Srinivasakannan and Subramanian, 1998; Choi et al., 2002) have conducted studies on multistage FB dryers to determine the drying behavior of materials such as ragi and millet. This energy and exergy research on continuous multistage FB dryers may encourage more research on different types of continuous dryers to ensure good product quality with lower energy use.

Yahya et al. (2017) designed and evaluated a hybrid, solar-biomass FB dryer. Their FB drying system included a solar collector and a biomass furnace. The solar-assisted FB dryer and biomass furnace were used to study the drying kinetics of rough rice. The average temperature of the drying air was $61^{\circ} \mathrm{C}$ and $78^{\circ} \mathrm{C}$. Rough rice with a moisture content of $20 \%$ (w.b.) was dried to $14 \%$ (w.b.) during 13.3 to $21.3 \mathrm{~min}$, and exergy efficiencies of $47.6 \%$ and $49.5 \%$ were reported for the temperatures of $61^{\circ} \mathrm{C}$ and $78^{\circ} \mathrm{C}$, respectively. The researchers suggested that most of the drying occurred in the falling rate period. The performance of the FB drying system was evaluated based on energy and exergy efficiencies. The specific energy consumption and drying time were lower with the solar-biomass FB drying system in comparison with solar dryers. Likewise, Sarker et al. (2015) determined the energy and exergy performance of an industrial FB dryer using rough rice. The maximum throughput of the dryer was $22 \mathrm{t} \mathrm{h}^{-1}$. Energy and exergy models, which were developed by applying the first and second laws of thermodynamics, were used to estimate the exergy efficiency during the drying process. The analysis showed that the energy utilization ratio varied from $5.24 \%$ to $13.92 \%$. On the other hand, the exergy efficiency varied from $46.99 \%$ to $58.14 \%$. A pure exergy balance revealed that only $31.18 \%$ to $37.01 \%$ of the exergy was used for drying rough rice, and the large amount of remaining exergy was wasted. The researchers were hopeful that the exergy can be increased in future studies, if sufficient insulation is installed on the dryer housing and the exhaust air is recycled.

As mentioned above, there are detailed studies on energy and exergy analyses of batch FB dryers, and a few studies on the energy and exergy efficiencies of continuous FB dryers. However, the available literature in this area is limited. Continuous FB dryers are more important for industrial applications because they can handle large throughputs.

\section{RESEARCH OPPORTUNITIES IN FB DRYING OF RICE}

As discussed above, FB drying could be a solution to the problem posed by the vast production of rough rice in the U.S. that needs rapid drying after harvest. The major shortcoming of FB dryers, as pointed out, is the development of moisture gradients during drying, which leads to rice fissuring and lowers the HRY. Therefore, the on-going debate among researchers on the effects of FB drying on rice quality requires thorough studies that focus on product quality. The following topics could be explored in future research on rice drying with FB dryers:

- Determine the maximum acceptable drying temperature that does not compromise rice quality, along with the corresponding rice variety. No explicit agreement on the optimum drying air temperature for rough rice can be concluded from the current literature.
- Study the use of moisture absorbents, rather than heating the air, to decrease the relative humidity of the drying air, which might enhance the drying rate during FB drying of rice.

- Explore the energy and exergy efficiencies during FB drying of rice. There is limited research on the energy and exergy efficiencies of FB dryers.

- Develop comprehensive numerical models for FB drying of rice that include the change in moisture on the surface of the kernels as well as within the kernels. There is currently a lack of such models, and such models could further support, or oppose, the use of FB drying for rice.

\section{Conclusions}

With increasing rice production in the U.S., post-harvest drying technology must be enhanced. FB drying technology for drying rice was reviewed, and this technology was found to have many advantages, including faster drying rates. This review also revealed that previous studies have reported a decrease in rice quality with FB drying; however, studies have suggested that drying temperatures below $60^{\circ} \mathrm{C}$ could help maintain rice quality. Other heating technologies, such as microwave and solar, and different structures to assist FB drying have had positive effects on the product quality and drying rate. Mathematical models have been developed to describe the FB drying of rice, but there is a lack of theoretical models that describe the internal and surface moisture kinetics of rice kernels. Thus, further research is needed to model the FB drying process to determine the optimum drying conditions. Research is also needed on the exergy and energy efficiencies related to FB drying of rice to further support, or oppose, the use of this drying technology in the U.S.

\section{REFERENCES}

Assari, M. R., Tabrizi, H. B., \& Najafpour, E. (2013). Energy and exergy analysis of fluidized bed dryer based on two-fluid modeling. Intl. J. Thermal Sci., 64, 213-219. https://doi.org/10.1016/j.ijthermalsci.2012.08.020

Atthajariyakul, S., \& Leephakpreeda, T. (2006). Fluidized bed paddy drying in optimal conditions via adaptive fuzzy logic control. J. Food Eng., 75(1), 104-114. https://doi.org/10.1016/j.jfoodeng.2005.03.055

Atwill II, R. L. (2015). Evaluation of water and nitrogen management practices in southern U.S. rice (Oryza sativa L.) production. Starkville, MS: Mississippi State University.

Avidan, A., \& Yerushalmi, J. (1985). Solids mixing in an expanded top fluid bed. AIChE J., 31(5), 835-841.

https://doi.org/10.1002/aic.690310520

Azadbakht, M., Aghili, H., Ziaratban, A., \& Torshizi, M. V. (2017). Application of artificial neural network method to exergy and energy analyses of fluidized bed dryer for potato cubes. Energy, 120, 947-958. https://doi.org/10.1016/j.energy.2016.12.006

Bagheri, I., Alizadeh, M. R., \& Safari, M. (2013). Varietal differences in physical and milling properties of paddy grains. Intl. J. Agric. Crop Sci. (IJACS), 5(6), 606-611.

Banaszek, M. M., \& Siebenmorgen, T. J. (1990). Moisture adsorption rates of rough rice. Trans. ASAE, 33(4), 1257-1262. https://doi.org/10.13031/2013.31465 
Basunia, M. A., \& Abe, T. (1998). Thin-layer drying characteristics of rough rice at low and high temperatures. Drying Tech., 16(35), 579-595. https://doi.org/10.1080/07373939808917425

Benado, A. L., \& Rizvi, S. S. H. (1985). Thermodynamic properties of water on rice as calculated from reversible and irreversible isotherms. J. Food Sci., 50(1), 101-105. https://doi.org/10.1111/j.1365-2621.1985.tb13286.x

Bizmark, N., Mostoufi, N., Sotudeh-Gharebagh, R., \& Ehsani, H. (2010). Sequential modeling of fluidized bed paddy dryer. $J$. Food Eng., 101(3), 303-308. https://doi.org/10.1016/j.jfoodeng.2010.07.015

Bonazzil, C., Courteis, F., Geneste, C., Lahon, M. C., \& Bimbent, J. (1997). Influence of drying conditions on the processing quality of rough rice. Drying Tech., 15(3-4), 1141-1157. https://doi.org/10.1080/07373939708917283

Brook, R. C. (1992). Drying cereal grains. In D. B. Sauer (Ed.), Storage of cereal grains and their products (pp. 183-218). St. Paul, MN: American Association of Cereal Chemists.

Brook, R. C., \& Foster, G. H. (1982). Drying, cleaning, and conditioning. In E. E. Finney (Ed.), Handbook of transportation and marketing in agriculture. Boca Raton, FL: CRC Press.

Burgschweiger, J., Groenewold, H., Hirschmann, C., \& Tsotsas, E. (1999). From hygroscopic single particle to batch fluidized bed drying kinetics. Canadian J. Chem. Eng., 77(2), 333-341. https://doi.org/10.1002/cjce.5450770220

Chen, C., \& Wu, P.-C. (2000). The study of interrupted drying technique for rough rice. Drying Tech., 18(10), 2381-2397. https://doi.org/10.1080/07373930008917848

Choi, K.-B., Park, S.-I., Park, Y.-S., Sung, S.-W., \& Lee, D.-H. (2002). Drying characteristics of millet in a continuous multistage fluidized bed. Korean J. Chem. Eng., 19(6), 11061111. https://doi.org/10.1007/BF02707240

Cnossen, A. G., \& Siebenmorgen, T. J. (2000). The glass transition temperature concept in rice drying and tempering: Effect on milling quality. Trans. ASAE, 43(6), 1661-1667. https://doi.org/10.13031/2013.3066

Cnossen, A. G., Jimenez, M. J., \& Siebenmorgen, T. J. (2003). Rice fissuring response to high drying and tempering temperatures. $J$. Food Eng., 59(1), 61-69. https://doi.org/10.1016/S02608774(02)00431-4

Da Silva, F. R. G. B., De Souza, M., Da Costa, A. M. D. S., De Matos Jorge, L. M., \& Paraiso, P. R. (2012). Experimental and numerical analysis of soybean meal drying in fluidized bed. Powder Tech., 229, 61-70. https://doi.org/10.1016/j.powtec.2012.06.008

Daud, W. R. W. (2008). Fluidized bed dryers: Recent advances. Adv. Powder Tech., 19(5), 403-418. https://doi.org/10.1016/S0921-8831(08)60909-7

Djaeni, M., Aishah, N. A., Nissaulfasha, H., \& Buchori, L. (2013). Corn drying with zeolite in the fluidized bed dryer under medium temperature. IPTEK J. Tech. Sci., 24(2). https://doi.org/10.12962/j20882033.v24i2.182

Gazor, H. R., \& Mohsenimanesh, A. (2010). Modelling the drying kinetics of canola in fluidised bed dryer. Czech J. Food Sci., 28(6), 531-537. https://doi.org/10.17221/256/2009-CJFS

Giner, S. A., \& Calvelo, A. (1987). Modelling of wheat drying in fluidized beds. J. Food Sci., 52(5), 1358-1363. https://doi.org/10.1111/j.1365-2621.1987.tb14082.x

Gong, Z. X., Devahastin, S., \& Mujumdar, A. S. (1997). A twodimensional finite element model for wheat drying in a novel rotating jet spouted bed. Drying Tech., 15(2), 575-592. https://doi.org/10.1080/07373939708917247

Gunhan, T., Demir, V., Hancioglu, E., \& Hepbasli, A. (2005). Mathematical modelling of drying of bay leaves. Energy Conv. Mgmt., 46(11), 1667-1679.

https://doi.org/10.1016/j.enconman.2004.10.001
Hemis, M., Watson, D. G., \& Raghavan, V. G. (2019). Modeling the drying of wheat seeds in a fluidized bed using a spatially resolved model. Appl. Eng. Agric., 35(4), 551-559. https://doi.org/10.13031/aea.13181

Huynh, L. X., Briens, C. L., Large, J. F., Catros, A., Bernard, J. R., \& Bergougnou, M. A. (1991). Hydrodynamics and mass transfer in an upward venturi/bubble column combination. Canadian J. Chem. Eng., 69(3), 711-722. https://doi.org/10.1002/cjce.5450690313

Inaba, H., Husain, S., Horibe, A., \& Haruki, N. (2007). Heat and mass transfer analysis of fluidized bed grain drying. Memoirs of the Faculty of Engineering, Okayama University, Vol. 41 (pp. 55-62). Retrieved from https://www.eng.okayama-u.ac.jp/wpcontent/uploads/2016/10/41_No6.pdf

Izadifar, M., \& Mowla, D. (2003). Simulation of a cross-flow continuous fluidized bed dryer for paddy rice. J. Food Eng., 58(4), 325-329. https://doi.org/10.1016/S0260-8774(02)00395-3

Jafari, A., \& Zare, D. (2017). Ultrasound-assisted fluidized bed drying of paddy: Energy consumption and rice quality aspects. Drying Tech., 35(7), 893-902.

https://doi.org/10.1080/07373937.2016.1230742

Jaiboon, P., Prachayawarakorn, S., Devahastin, S., \& Soponronnarit, S. (2009). Effects of fluidized bed drying temperature and tempering time on quality of waxy rice. J. Food Eng., 95(3), 517-524. https://doi.org/10.1016/j.jfoodeng.2009.06.019

Jaiboon, P., Prachayawarakorn, S., Devahastin, S., Tungtrakul, P., \& Soponronnarit, S. (2011). Effect of high-temperature fluidized-bed drying on cooking, textural and digestive properties of waxy rice. J. Food Eng., 105(1), 89-97. https://doi.org/10.1016/j.jfoodeng.2011.02.008

Jittanit, W., Saeteaw, N., \& Charoenchaisri, A. (2010). Industrial paddy drying and energy saving options. J. Stored Prod. Res., 46(4), 209-213. https://doi.org/10.1016/j.jspr.2010.04.005

Karbasi, A., \& Mahdizadeh, Z. (2008). Drying rough rice in a fluidized bed dryer. J. Agric. Sci. Tech., 10, 233-241.

Karagüzel, I., Tekin, E., \& Topuz, A. (2012). Energy and exergy analysis of fluidized bed drying of chickpea and bean. Sci. Res. Essays, 7(46), 3961-3973. https://doi.org/10.5897/SRE11.2003

Kassem, A. S., Shokr, A. Z., El-Mahdy, A. R., Aboukarima, A. M., \& Hamed, E. Y. (2011). Comparison of drying characteristics of Thompson seedless grapes using combined microwave oven and hot air drying. J. Saudi Soc. Agric. Sci., 10(1), 33-40. https://doi.org/10.1016/j.jssas.2010.05.001

Kauffman, C. W. (1987). Recent dust explosion experiences in the U.S. grain industry. In K. L. Cashdollar \& M. Hertzberg (Eds.), Industrial dust explosions (pp. 243-267). West Conshohocken, PA: ASTM. https://doi.org/10.1520/STP28178S

Khanali, M., Rafiee, S., \& Jafari, A. (2014). Numerical simulation and experimental investigation of plug-flow fluidized bed drying under dynamic conditions. J. Food Eng., 137, 64-75. https://doi.org/10.1016/j.jfoodeng.2014.03.020

Khanali, M., Sh, R., Jafari, A., Hashemabadi, S. H., \& Banisharif, A. (2012). Mathematical modeling of fluidized bed drying of rough rice (Oryza sativa L.) grain. J. Agric. Tech., 8(3), 795810.

Knowlton, T. M., Karri, S. B., \& Issangya, A. (2005). Scale-up of fluidized-bed hydrodynamics. Powder Tech., 150(2), 72-77. https://doi.org/10.1016/j.powtec.2004.11.036

Kozanoglu, B., Mazariegos, D., Guerrero-Beltran, J. A., \& WeltiChanes, J. (2013). Drying kinetics of paddy in a reduced pressure superheated steam fluidized bed. Drying Tech., 31(4), 452-461. https://doi.org/10.1080/07373937.2012.740543

Kunze, O. R. (1983). Physical properties of rice related to drying the grain. Drying Tech., 2(3), 369-387. http://doi.org/10.1080/07373938308959837 
Kunze, O. R., \& Calderwood, D. L. (2004). Rough rice drying moisture adsorption and desorption. In E. T. Champagne (Ed.), Rice: Chemistry and technology (Vol. 3, pp. 223-268). St Paul, MN: American Association of Cereal Chemists. https://doi.org/10.1094/1891127349.009

Liebanes, M. D., Aragon, J. M., Palancar, M. C., Arevalo, G., \& Jimenez, D. (2006). Fluidized bed drying of two-phase olive oil mill by-products. Drying Tech., 24(12), 1609-1618. https://doi.org/10.1080/07373930601031059

Luthra, K., \& Sadaka, S. (2019). Effects of air dehumidification on the performance of a fluidized bed dryer and the rice quality. ASABE Paper No. 1900322. St. Joseph, MI: ASABE. https://doi.org/10.13031/aim.201900322

Luthra, K., Sadaka, S., \& Atungulu, G. G. (2018). Exploration of rough rice head yield subjected to drying and retention durations in a fluidized bed system. Appl. Eng. Agric., 34(5), 877-885. https://doi.org/10.13031/aea.12925

Martinez-Vera, C., Vizearra-Mendoza, M., Galin-Domingo, O., \& Ruiz-Martinez, R. (1995). Experimental validation of a mathematical model for the batch drying of corn grains. Drying Tech., 13(1-2), 333-350. https://doi.org/10.1080/07373939508916956

Matsen, J. M. (1996). Scale-up of fluidized bed processes: Principle and practice. Powder Tech., 88(3), 237-244. https://doi.org/10.1016/S0032-5910(96)03126-9

Meeso, N., Nathakaranakule, A., Madhiyanon, T., \& Soponronnarit, S. (2004). Influence of FIR irradiation on paddy moisture reduction and milling quality after fluidized bed drying. J. Food Eng., 65(2), 293-301. https://doi.org/10.1016/j.jfoodeng.2004.01.033

Meeso, N., Nathakaranakule, A., Madhiyanon, T., \& Soponronnarit, S. (2007). Modelling of far-infrared irradiation in paddy drying process. J. Food Eng., 78(4), 1248-1258. https://doi.org/10.1016/j.jfoodeng.2006.01.003

Midilli, A., Kucuk, H., \& Yapar, Z. (2002). A new model for singlelayer drying. Drying Tech. 20(7), 1503-1513. https://doi.org/10.1081/DRT-120005864

Misra, M. K., \& Brooker, D. B. (1980). Thin-layer drying and rewetting equations for shelled yellow corn. Trans. ASAE, 23(5), 1254-1260. https://doi.org/10.13031/2013.34756

Mrema, G. C., Gumbe, L. O., Chepete, H. J., \& Agullo, J. O. (2012). Rural structures in the tropics: Design and development. Rome, Italy: United Nations FAO.

Nazghelichi, T., Aghbashlo, M., Kianmehr, M. H., \& Omid, M. (2011). Prediction of energy and exergy of carrot cubes in a fluidized bed dryer by artificial neural networks. Drying Tech., 29(3), 295-307. https://doi.org/10.1080/07373937.2010.494237

Nejadi, J., \& Nikbakht, A. M. (2017). Numerical simulation of corn drying in a hybrid fluidized bed-infrared dryer. J. Food Proc. Eng., 40(2), e12373. https://doi.org/10.1111/jfpe.12373

Ondier, G. O., Siebenmorgen, T. J., \& Mauromoustakos, A. (2010). Equilibrium moisture contents of rough rice dried using hightemperature, fluidized-bed conditions. Trans. ASABE, 53(5), 1667-1672. https://doi.org/10.13031/2013.34885

Ozahi, E., \& Demir, H. (2013). A model for the thermodynamic analysis in a batch-type fluidized bed dryer. Energy, 59, 617624. https://doi.org/10.1016/j.energy.2013.07.001

Patel, N., Jagan, S. K., Jha, S. K., Sinha, J. P., \& Kumar, A. (2013). Physical properties of basmati varieties of paddy. J. Agric. Eng., 50(4), 39-47.

Poomsa-ad, N., Soponronnarit, S., Terdyothin, A., \& Prachayawarakorn, S. (2001). Head rice yield after drying by fluidization technique and tempering. Proc. 2nd Asian-Oceania Drying Conf. (pp. 20-22).

Poomsa-ad, N., Terdyothin, A., Prachayawarakorn, S., \& Soponronnarit, S. (2005). Investigations on head-rice yield and operating time in the fluidised-bed drying process: Experiment and simulation. J. Stored Prod. Res., 41(4), 387-400. https://doi.org/10.1016/j.jspr.2004.06.002

Prachayawarakorn, S., Saniso, E., Swasdisewi, T., \& Soponronnarit, S. (2018). Process of parboiling rice by microwave-assisted hot air fluidized bed technique. Proc. 21st Intl. Drying Symp. (pp. 1615-1612). Valencia, Spain: Universitat Politecnica de Valencia. https://doi.org/10.4995/IDS2018.2018.7541

Prakash, B., \& Pan, Z. (2011). Modeling moisture movement in rice. In Advanced Topics in Mass Transfer (pp. 283-304). Rijeka, Croatia: InTech. https://doi.org/10.5772/15317

Prasad, B. V. S., Chandra, P. K., \& Bal, S. (1994). Drying parboiled rough rice in stationary, semi-fluidized, and fluidized conditions. Trans. ASAE, 37(2), 589-594. https://doi.org/10.13031/2013.28117

Proctor, D. L. (1994). Grain storage techniques: Evolution and trends in developing countries. Rome, Italy: United Nations FAO.

Ramesh, M. N., \& Rao, P. S. (1996). Drying studies of cooked rice in a vibrofluidised bed dryer. J. Food Eng., 27(4), 389-396. https://doi.org/10.1016/0260-8774(95)00018-6

Rattanamechaiskul, C., Junka, N., Wongs-Aree, C., Prachayawarakorn, S., \& Soponronnarit, S. (2016). Influence of hot air fluidized bed drying on quality changes of purple rice. Drying Tech., 34(12), 1462-1470. https://doi.org/10.1080/07373937.2015.1126720

Reay, D., \& Baker, C. G. J. (1985). Chapter 16: Drying. In D. Harrison, R. Clift, \& J. F. Davidson (Eds.), Fluidization (2nd Ed.). London, UK: Academic Press.

Reddy, K. R. N., Reddy, C. S., Abbas, H. K., Abel, C. A., \& Muralidharan, K. (2008). Mycotoxigenic fungi, mycotoxins, and management of rice grains. Toxin Rev., 27(3-4), 287-317. https://doi.org/10.1080/15569540802432308

Reyes, A., Ceron, S., Zuniga, R., \& Moyano, P. (2007). A comparative study of microwave-assisted air drying of potato slices. Biosyst. Eng., 98(3), 310-318. https://doi.org/10.1016/j.biosystemseng.2007.07.006

Richardson, J. (1971). Incipient fluidization and particulate systems. In J. F. Davidson \& D. Harrison (Eds.), Fluidization (Vol. 2, pp. 25-64). London, UK: Academic Press.

Rordprapat, W., Nathakaranakule, A., Tia, W., \& Soponronnarit, S. (2005). Comparative study of fluidized bed paddy drying using hot air and superheated steam. J. Food Eng., 71(1), 28-36. https://doi.org/10.1016/j.jfoodeng.2004.10.014

Roy, G. K., \& Sarma, K. J. R. (1970). Fluidized bed heat transfer. Chem. Proc. Eng. (Feb. 1970), 17-24.

Sadaka, S. (2014). Selection, performance, and maintenance of grain bin fans. Fayetteville, AR: University of Arkansas Cooperative Extension Service.

Sadaka, S. S., Luthra, K., \& Atungulu, G. G. (2018). Evaluation of the performance of a custom-made fluidized bed drying system. Appl. Eng. Agric., 34(6), 1027-1037.

https://doi.org/10.13031/aea.12909

Sarker, M. S. H., Hasan, S. M., Ibrahim, M. N., Aziz, N. A., \& Punan, M. S. (2017). Mechanical property and quality aspects of rice dried in industrial dryers. J. Food Sci. Tech., 54(12), 41294134. https://doi.org/10.1007/s13197-017-2856-5

Sarker, M. S. H., Ibrahim, M. N., Abdul Aziz, N., \& Mohd. Salleh, P. (2014). Energy and rice quality aspects during drying of freshly harvested paddy with industrial inclined bed dryer. Energy Conv. Mgmt., 77, 389-395. https://doi.org/10.1016/j.enconman.2013.09.038

Sarker, M. S. H., Ibrahim, M. N., Abdul Aziz, N., \& Punan, M. S. (2015). Energy and exergy analysis of industrial fluidized bed drying of paddy. Energy, 84, 131-138. https://doi.org/10.1016/j.energy.2015.02.064 
Sarker, M. S. H., Ibrahim, M. N., Abdul Aziz, N., \& Punan, M. S. (2013). Drying kinetics, energy consumption, and quality of paddy (MAR-219) during drying by the industrial inclined bed dryer with or without the fluidized bed dryer. Drying Tech., 31(3), 286-294. https://doi.org/10.1080/07373937.2012.728270

Schluterman, D. A., \& Siebenmorgen, T. J. (2007). Relating rough rice moisture content reduction and tempering duration to head rice yield reduction. Trans. ASABE, 50(1), 137-142. https://doi.org/10.13031/2013.22385

Sharada, S. (2013). Studies on effect of various operating parameters and foaming agents: Drying of fruits and vegetables. Intl. J. Modern Eng. Res., 3(3), 1512-1519.

Sopanronnarit, S., Rordprapat, W., \& Wetchacama, S. (1998). Mobile fluidized bed paddy dryer. Drying Tech., 16(7), 15011513. https://doi.org/10.1080/07373939808917473

Soponronnarit, S. (1999). Fluidised-bed paddy drying. Science Asia, 25(1), 51-56. https://doi.org/10.2306/scienceasia15131874.1999.25.051

Soponronnarit, S., \& Prachayawarakorn, S. (1994). Optimum strategy for fluidized bed paddy drying. Drying Tech., 12(7), 1667-1686. https://doi.org/10.1080/07373939408962192

Soponronnarit, S., Nathakaranakule, A., Jirajindalert, A., \& Taechapairoj, C. (2006a). Parboiling brown rice using superheated steam fluidization technique. J. Food Eng., 75(3), 423-432. https://doi.org/10.1016/j.jfoodeng.2005.04.058

Soponronnarit, S., Prachayawarakorn, S., Rordprapat, W., Nathakaranakule, A., \& Tia, W. (2006b). A superheated-steam fluidized-bed dryer for parboiled rice: Testing of a pilot-scale and mathematical model development. Drying Tech., 24(11), 1457-1467. https://doi.org/10.1080/07373930600952800

Srimitrungroj, T., Soponronarit, S., Prachayawarakorn, S., \& Nathakaranakule, A. (2019). Evaluation of new parboiled rice process using humidified hot air fluidized bed drying. Drying Tech., 37(8), 1044-1052. https://doi.org/10.1080/07373937.2018.1485692

Srinivasaannan, C., Subba Rao, S., \& Varma, Y. B. (1994). A study of stable range of operation in multistage fluidised beds. Powder Tech., 78(3), 203-211. https://doi.org/10.1016/00325910(93)02785-9

Srinivasakannan, C., \& Balasubramaniam, N. (2006). An experimental and modeling investigation on drying of ragi (Eleusine corocana) in fluidized bed. Drying Tech., 24(12), 1683-1689. https://doi.org/10.1080/07373930601031588

Srinivasakannan, C., \& Balasubramanian, N. (2008). An analysis on modeling of fluidized bed drying of granular material. $A d v$. Powder Tech., 19(1), 73-82. https://doi.org/10.1163/156855208X291774

Srinivasakannan, C., \& Subramanian, N. B. (1998). Some drying aspects of multistage fluidized beds. Chem. Eng. Tech., 21(12), 961-966. https://doi.org/10.1002/(sici)15214125(199812)21:12<961::aid-ceat961>3.0.co;2-0

Srinivasakannan, C., Al Shoaibi, A., \& Balasubramanian, N. (2012). Continuous fluidized bed drying with and without internals: Kinetic model. Chem. Biochem. Eng. Qtly., 26(2), 97104.

Stakic, M., \& Urosevic, T. (2011). Experimental study and simulation of vibrated fluidized bed drying. Chem. Eng. Proc.: Proc. Intensif., 50(4), 428-437. https://doi.org/10.1016/j.cep.2011.02.006

Sutherland, J., \& Ghaly, T. (1990). Rapid fluid-bed drying of paddy rice in the humid tropics. Proc. 13th ASEAN Seminar on Postharvest Technology.

Taechapairoj, C., Dhuchakallaya, I., Soponronnarit, S., Wetchacama, S., \& Prachayawarakorn, S. (2003). Superheated steam fluidised bed paddy drying. J. Food Eng., 58(1), 67-73. https://doi.org/10.1016/S0260-8774(02)00335-7
Tahmasebi, A., Yu, J., Han, Y., Zhao, H., \& Bhattacharya, S. (2014). A kinetic study of microwave and fluidized-bed drying of a Chinese lignite. Chem. Eng. Res. Design, 92(1), 54-65. https://doi.org/10.1016/j.cherd.2013.06.013

Taweerattanapanish, A., Soponronnarit, S., Wetchakama, S., Kongseri, N., \& Wongpiyachon, S. (1999). Effects of drying on head rice yield using fluidization technique. Drying Tech., 17(12), 346-353. https://doi.org/10.1080/07373939908917535

Temple, S. J., van Boxtel, A. J. B., \& van Straten, G. (2000). Control of fluid bed tea dryers: Controller performance under varying operating conditions. Comput. Electron. Agric., 29(3), 217-231. https://doi.org/10.1016/S0168-1699(00)00148-4

Thakur, A. K., \& Gupta, A. K. (2006). Stationary versus fluidizedbed drying of high-moisture paddy with rest period. Drying Tech., 24(11), 1443-1456. https://doi.org/10.1080/07373930600952792

Tirawanichakul, S., Prachayawarakorn, S., Varanyanond, W., Tungtrakul, P., \& Soponronnarit, S. (2004). Effect of fluidized bed drying temperature on various quality attributes of paddy. Drying Tech., 22(7), 1731-1754. https://doi.org/10.1081/DRT200025634

Topuz, A., Gur, M., \& Gul, M. Z. (2004). An experimental and numerical study of fluidized bed drying of hazelnuts. Appl. Thermal Eng., 24(10), 1535-1547. https://doi.org/10.1016/j.applthermaleng.2003.11.020

Truong, T., Truong, V., Fukai, S., \& Bhandari, B. (2019). Changes in physicochemical properties of rice in response to hightemperature fluidized bed drying and tempering. Drying Tech., 37(3), 331-340. https://doi.org/10.1080/07373937.2018.1452031

Tuyen, T. T., Truong, V., Fukai, S., \& Bhandari, B. (2009). Effects of high-temperature fluidized bed drying and tempering on kernel cracking and milling quality of Vietnamese rice varieties. Drying Tech., 27(3), 486-494. https://doi.org/10.1080/07373930802686099

Ulku, S., \& Uckan, G. (1986). Corn drying in fluidized beds. Drying, 86(2), 531-536.

USDA-ERS. (2018). Rice yearbook. Washington, DC: USDA Economic Research Service. Retrieved from https://www.ers.usda.gov/data-products/rice-yearbook/riceyearbook/\#All

Villegas, J. A., Duncan, S. R., Wang, H. G., Yang, W. Q., \& Raghavan, R. S. (2010). Optimal operating conditions for a batch fluidised bed dryer. IET Control Theory Appl., 4(2), 294302. https://doi.org/10.1049/iet-cta.2009.0039

Villegas, J. A., Li, M., Duncan, S. R., Wang, H. G., \& Yang, W. (2008). Modeling and control of moisture content in a batch fluidized bed dryer using tomographic sensor. Proc. American Control Conf. (pp. 3350-3355). https://doi.org/10.1109/ACC.2008.4587009

Wetchacama, S., Soponronnarit, S., \& Jariyatontivait, W. (2000). Development of a commercial scale vibro-fluidized bed paddy dryer. Kasetsart J. Nat. Sci., 34(3), 423-430.

Wimberly, J. E. (1983). Technical handbook for the paddy rice postharvest industry in developing countries. Manila, Philipines: International Rice Research Institute.

Wiset, L., Srzednicki, G., Driscoll, R., Nimmuntavin, C., \& Siwapornak, P. (2001). Effects of high-temperature drying on rice quality. CIGR E-J., 3, manuscript FP 01 003. Retrieved from https://cigrjournal.org/index.php/Ejounral/article/view/191/185

Wu, B., Yang, W., \& Jia, C. (2004). A three-dimensional numerical simulation of transient heat and mass transfer inside a single rice kernel during the drying process. Biosyst. Eng., 87(2), 191-200. https://doi.org/10.1016/j.biosystemseng.2003.09.004

Xiao, Z., Zhang, F., Wu, N., \& Liu, X. (2012). CFD modeling and simulation of superheated steam fluidized bed drying process. 
Proc. Intl. Conf. on Computer and Computing Technologies in Agriculture (pp. 141-149). Berlin, Germany: Springer. https://doi.org/10.1007/978-3-642-36124-1_18

Yahya, M. (2016). Performance analysis of solar-assisted fluidized bed dryer integrated biomass furnace with and without heat pump for drying of paddy. Intl. J. Photoenergy, 2016, article 3801918. http://dx.doi.org/10.1155/2016/3801918

Yahya, M., Fudholi, A., \& Sopian, K. (2017). Energy and exergy analyses of solar-assisted fluidized bed drying integrated with biomass furnace. Renew. Energy, 105, 22-29. https://doi.org/10.1016/j.renene.2016.12.049

Yang, W., Jia, C. C., Siebenmorgen, T. J., Howell, T. A., \& Cnossen, A. G. (2002). Intra-kernel moisture responses of rice to drying and tempering treatments by finite element simulation.
Trans. ASAE, 45(4), 1038-1044.

https://doi.org/10.13031/2013.9917

Yogendrasasidhar, D., \& Pydi Setty, Y. (2018). Drying kinetics, exergy, and energy analyses of kodo millet grains and fenugreek seeds using wall heated fluidized bed dryer. Energy, 151, 799811. https://doi.org/10.1016/j.energy.2018.03.089

Zahed, A. H., Zhu, J. X., \& Grace, J. R. (1995). Modelling and simulation of batch and continuous fluidized bed dryers. Drying Tech., 13(1-2). https://doi.org/10.1080/07373939508916940

Zare, D., Jayas, D. S., \& Singh, C. B. (2012). A generalized dimensionless model for deep bed drying of paddy. Drying Tech., 30(1), 44-51.

https://doi.org/10.1080/07373937.2011.615429 